\title{
Pengaruh Kualitas Audit, Size, Leverage, dan Kepemilikan Keluarga pada Agresivitas Pajak
}

\section{Nyoman Yudha Astriayu Widyari ${ }^{1}$ Ni Ketut Rasmini ${ }^{2}$}

\author{
${ }^{1,2}$ Fakultas Ekonomi dan Bisnis Universitas Udayana (Unud), Bali, Indonesia \\ e-mail: astriayuwidyari@gmail.com
}

\begin{abstract}
ABSTRAK
Penelitian ini bertujuan untuk mengetahui pengaruh kualitas audit, size, leverage, dan kepemilikan keluarga pada agresivitas pajak yang diukur dengan proksi effective tax rate, cash effective tax rate, dan book tax difference. Populasi pada penelitian ini adalah perusahaan manufaktur yang terdaftar di Bursa Efek Indonesia tahun 2013-2017. Metode penentuan sampel menggunakan metode non probability sampling dengan teknik purposive sampling dan diperoleh 125 pengamatan. Teknik analisis data yang digunakan adalah regresi linear berganda. Hasil analisis menunjukkan bahwa kualitas audit berpengaruh negatif pada agresivitas pajak yang diukur dengan cash effective tax rate (CETR) dan berpengaruh positif pada agresivitas pajak dengan menggunakan proksi book tax difference (BTD). Size berpengaruh negatif pada agresivitas pajak yang diukur dengan effective tax rate (ETR) dan book tax difference (BTD). Leverage berpengaruh positif pada agresivitas pajak yang diukur dengan effective tax rate (ETR). Kepemilikan keluarga berpengaruh positif pada agresivitas pajak yang diukur dengan cash effective tax rate.
\end{abstract}

Kata kunci : Kualitas audit, size leverage, kepemilikan keluarga, agresivitas pajak

\begin{abstract}
This study aims to obtain empirical evidence of the effect of audit quality, size, leverage, and family ownerships on tax aggressiveness. The population of this research is manufacturing company listed on the Indonesia Stock Exchange in 2013-2017. The method of determining sample using non probability sampling method with purposive sampling technique and obtained 125 observations. Data analysis techniques uisng multiple linear regression. The result of analysis shows that audit quality has a negative effect on tax aggressiveness measured by cash effective tax rate (CETR) and has positive effect on tax aggressiveness measured by book tax difference (BTD). Size has a negative effect on tax aggressiveness measured by effective tax rate (ETR) and book tax difference 9BTD). Leverage has a positive effect on tax aggressiveness measured by effective tax rate (ETR). Family ownerships has a positive effect on tax aggressiveness measured by cash effective tax rate.
\end{abstract}

Keywords: Audit quality, size, leverage, family ownerships, tax aggressiveness

\section{PENDAHULUAN}

Pemerintah menekankan pendapatan negara yang berasal dari pajak karena digunakan sebagai sumber untuk mengalokasikan dana bagi Anggaran Pendapatan 
Belanja Negara (APBN). Realisasi penerimaan pajak di Indonesia tahun 2013 hingga 2017 dijelaskan pada Tabel 1.

Tabel 1.

Realisasi Penerimaan Pajak Tahun 2013-2017 (dalam Triliun Rupiah)

\begin{tabular}{ccccc}
\hline \multirow{2}{*}{ No. } & \multirow{2}{*}{ Tahun } & $\begin{array}{c}\text { Target Penerimaan } \\
\text { Pajak }\end{array}$ & $\begin{array}{c}\text { Realisasi Penerimaan } \\
\text { Pajak }\end{array}$ & $\begin{array}{c}\text { Persentase Realisasi } \\
\text { Penerimaan }\end{array}$ \\
\hline 1. & 2013 & $1.148,4$ & $1.071,1$ & 93,0 persen \\
2. & 2014 & $1.246,1$ & $1.143,0$ & 91,7 persen \\
3. & 2015 & $1.489,3$ & $1.240,4$ & 83,3 persen \\
4. & 2016 & $1.539,2$ & $1.284,8$ & 83,5 persen \\
5. & 2017 & $1.283,6$ & $1.151,5$ & 89,7 persen \\
\hline \multicolumn{5}{l}{ Sumber: www.kemenkeu.go.id, 2018}
\end{tabular}

Berdasarkan Tabel 1. dapat disimpulkan bahwa realisasi penerimaan pajak di Indonesia mengalami peningkatan dari tahun 2013-2017, namun realisasi penerimaan pajak ini masih belum sesuai dengan target yang diharapkan. Hal tersebut menyebabkan timbulnya pertanyaan apakah wajib pajak melakukan tindakan-tindakan berupa penghindaran pajak dan penggelapan pajak. Salah satu tindakan yang dapat diambil perusahaan untuk meminimalkan beban pajaknya adalah dengan tax planning atau agresivitas pajak. Frank et al.(2009) mendefinisikan agresivitas pajak sebagai suatu langkah atau tindakan yang dilakukan oleh perusahaan dengan merekayasa beban pajaknya melalui tindakan perencanaan pajak, baik menggunakan cara yang legal (tax avoidance) ataupun cara ilegal (tax evasion).

Salah satu variabel yang digunakan untuk melihat indikasi adanya penghindaran pajak dalam perusahaan adalah kualitas audit. Kualitas audit adalah kinerja auditor dalam mengaudit laporan keuangan perusahaan berdasarkan Standar Profesional Akuntan Publik (SPAP), keahlian auditor, dan kode etik profesi akuntan publik (Deangelo, 1981). Perusahaan dengan audit yang berkualitas cenderung tidak melakukan manipulasi laba untuk kepentingan 
perpajakan. Penelitian yang dilakukan oleh Aditama (2016) menyatakan bahwa kualitas audit tidak berpengaruh pada agresivitas pajak. Hasil yang berbeda diperoleh dari penelitian Eksandy (2017) yang menunjukkan bahwa kualitas audit berpengaruh positif pada agresivitas pajak.

Variabel lain yang dapat mempengaruhi agresivitas pajak adalah ukuran perusahaan. Ukuran perusahaan adalah skala untuk mengukur besar kecilnya perusahaan melalui jumlah aset yang dimiliki perusahaan (Rodriguez dan Arias, 2012). Perusahaan yang memiliki aset dalam jumlah besar cenderung menghasilkan laba yang optimal serta berpengaruh pada jumlah pajak yang harus dibayarkan oleh perusahaan tersebut (Dharma dan Ardiana, 2016). Penelitian yang dilakukan oleh Kurniasih dan Sari (2013) menyatakan bahwa size berpengaruh negatif terhadap perencanaan pajak. Berbeda dengan penelitian yang dilakukan oleh Mustika dkk. (2017) dengan hasil bahwa ukuran perusahaan tidak berpengaruh pada agresivitas pajak.

Tindakan perusahaan dalam melakukan penghindaran pajak dapat dilihat dari kebijakan pendanaan yang diambil perusahaan. Salah satu kebijakan pendanaan adalah leverage. Leverage adalah rasio yang menunjukkan besarnya modal perusahaan yang diperoleh dari pihak eksternal sebagai biaya untuk melakukan berbagai kegiatan operasionalnya (Kasmir, 2014: 112). Penelitian Tiaras dan Wijaya (2015) serta Arianandini dan Ramantha (2018) memperoleh hasil bahwa leverage tidak berpengaruh pada agresivitas pajak. Berbeda dengan Fadli dkk. (2016) yang menyatakan bahwa leverage berpengaruh terhadap agresivitas pajak. 
Menurut data Indonesian Institute for Corporate and Directorship lebih dari 95 persen bisnis di Indonesia adalah perusahaan yang dimiliki oleh keluarga. Penelitian Chen et al. (2010) menjelaskan bahwa perusahaan keluarga kurang agresif untuk membayar pajak dibandingkan perusahaan non-keluarga karena perusahaan non-keluarga cenderung memiliki masalah keagenan yang lebih besar akibat dari adanya konflik antara manajer dengan pemilik perusahaan. Berbeda dengan penelitian Sari dan Martani (2010) yang menyatakan bahwa perusahaan dengan kepemilikan keluarga memiliki tindakan pajak agresif yang lebih tinggi karena perusahaan memeroleh keuntungan berupa penghematan pajak dan rent extraction. Keuntungan tersebut lebih besar dibandingkan kerugian yang akan dihadapi perusahaan seperti menurunnya harga saham, kredibilitas perusahaan, maupun kemungkinan terkena hukuman dari fiskus.

Agresivitas pajak dalam penelitian ini diukur dengan tiga model pengukuran yaitu effective tax rate (ETR), cash effective tax rate (CETR), dan book tax difference (BTD). Ketiga model memiliki tujuan berbeda. Penelitian ini mereplikasi dua literatur yang telah dilakukan oleh peneliti terdahulu. Penelitian Rusydi dan Martani (2016) meneliti pengaruh struktur kepemilikan terhadap agresivitas pajak dengan tiga proksi yaitu effective tax rate (ETR), cash effective tax rate (CETR), dan book tax difference (BTD). Selanjutnya penelitian Putri (2016) meneliti pengaruh kepemilikan keluarga, leverage, dan ukuran perusahaan pada agresivitas pajak di sektor manufaktur yang terdaftar di BEI. Hal inilah yang memotivasi peneliti untuk kembali meneliti mengenai pengaruh kualitas audit, size, leverage, dan kepemilikan keluarga pada agresivitas pajak. 
Teori keagenan oleh Jensen dan Meckling (1976) menjelaskan hubungan antara pemilik perusahaan dan manajemen dari adanya suatu kontrak yang efisien. Keputusan perusahaan untuk melakukan tindakan agresivitas pajak merupakan salah satu masalah keagenan. Masalah ini timbul karena ada perbedaan kepentingan antara manajer dan pemilik perusahaan. Salah satu cara yang dapat dilakukan oleh pemilik perusahaan untuk meminimalisir adanya asimetri informasi dalam perusahaan adalah dengan menggunakan auditor bekualitas dalam mengaudit laporan keuangannya (Khairunisa dkk., 2017). Penelitian Dewi dan Jati (2014) menyatakan bahwa Kantor Akuntan Publik The Big Four lebih kompeten dan profesional dibandingkan Kantor Akuntan Publik non The Big Four, sehingga hasil auditan yang dihasilkan dianggap lebih berkualitas. Penelitian Kanagaretnam et al. (2016) dan Khairunisa dkk. (2017) menyatakan bahwa kualitas audit berpengaruh negatif pada agresivitas pajak. Berdasarkan uraian di atas maka hipotesis penelitian ini adalah sebagai berikut.

$\mathrm{H}_{1 \mathrm{a}}$ : Kualitas audit berpengaruh negatif pada agresivitas pajak (effective tax rate). $\mathrm{H}_{1 \mathrm{~b}}$ : Kualitas audit berpengaruh negatif pada agresivitas pajak (cash effective tax rate).

$\mathrm{H}_{1 \mathrm{c}}$ :Kualitas audit berpengaruh negatif pada agresivitas pajak (book tax difference).

Salah satu dari tiga teori dalam teori akuntansi positif yaitu Political Cost Hypothesis oleh Watts dan Zimmerman (1990) menjelaskan bahwa perusahaan yang membayar biaya politis dalam jumlah besar cenderung akan melakukan tindakan untuk menurunkan labanya dengan menggunakan metode akuntansi yang sesuai. Besarnya ukuran perusahaan dan pertambahan nilai perusahaan akan menarik perhatian bagi para stakeholders yakni pemerintah, debitur, kreditur, dan 
lainnya. Kondisi tersebut akan menimbulkan besarnya biaya politik yang harus dikeluarkan oleh perusahaan (Wirawan dan Sukartha, 2018). Chu (2009) menyatakan bahwa perusahaan yang termasuk dalam skala perusahaan besar memiliki sumber daya yang berlimpah untuk digunakan dalam memenuhi tujuantujuan tertentu. Penelitian yang dilakukan oleh Richardson dan Lanis (2007) memperoleh hasil bahwa semakin besar perusahaan maka semakin tinggi agresivitas pajak yang dilakukan perusahaan tersebut. Berdasarkan uraian di atas maka hipotesis penelitian ini adalah sebagai berikut.

$\mathrm{H}_{2 \mathrm{a}}$ : Size berpengaruh positif pada agresivitas pajak (effective tax rate). $\mathrm{H}_{2 \mathrm{~b}}$ : Size berpengaruh positif pada agresivitas pajak (cash effective tax rate). $\mathrm{H}_{2 \mathrm{c}}$ : Size berpengaruh positif pada agresivitas pajak (book tax difference).

Teori akuntansi positif yaitu hipotesis debt covenant menjelaskan bahwa perusahaan yang memiliki keterikatan kontrak dengan pihak ketiga yakni kreditur, akan menjaga laba periode berjalan dengan tujuan menjaga stabilitas kinerja perusahaan. Hal tersebut disebabkan oleh adanya kepentingan perusahaan dengan kreditur yang semakin tinggi, sehingga pengawasan yang dilakukan oleh kreditur akan meningkat untuk menjamin kelangsungan pinjaman modal eksternal. Tingginya rasio leverage menyebabkan perusahaan semakin agresif dalam hal perpajakan. Perusahaaan harus mempertahankan laba mereka karena adanya keterikatan dengan kreditur. Perusahaan memiliki beban pajak yang besar, apabila perusahaan berusaha meningkatkan laba mereka (Adisamartha dan Noviari, 2015). Kondisi tersebut sejalan dengan penelitian yang dilakukan oleh Putri (2016) yang menyatakan bahwa semakin tinggi leverage, maka semakin rendah 
agresivitas pajak perusahaan. Berdasarkan uraian di atas maka hipotesis penelitian ini adalah sebagai berikut.

$\mathrm{H}_{3 \mathrm{a}}$ : Leverage berpengaruh negatif pada agresivitas pajak (effective tax rate). $\mathrm{H}_{3 \mathrm{~b}}$ : Leverage berpengaruh negatif pada agresivitas pajak (cash effective tax rate). $\mathrm{H}_{3 \mathrm{c}}$ : Leverage berpengaruh negatif pada agresivitas pajak (book tax difference).

Pemilikan terkosentrasi seperti kepemilikan keluarga dapat digunakan untuk mengurangi masalah keagenan (Chen et al., 2010). Masalah agensi yang timbul dalam perusahaan dengan kepemilikan keluarga dapat lebih diminimalisir dibandingkan dengan perusahaan yang dikendalikan oleh publik atau perusahaan tanpa pengendali utama (Wijayani, 2016). Perusahaan keluarga cenderung dapat melakukan kontrol yang lebih tinggi dibandingkan perusahaan non-keluarga dalam mengawasi kinerja perusahaan. Kondisi tersebut menyebabkan berkurangnya agency cost yang harus dikeluarkan karena banyak pihak yang terlibat langsung untuk mengawasi tindakan manajemen (Chu, 2009). Penelitian yang dilakukan oleh Chen et al. (2010) menyatakan bahwa perusahaan keluarga cenderung tidak agresif dalam hal perpajakan. Berdasarkan uraian di atas maka hipotesis penelitian ini adalah sebagai berikut.

$\mathrm{H}_{4 \mathrm{a}}$ : Kepemilikan keluarga berpengaruh negatif pada agresivitas pajak (effective tax rate).

$\mathrm{H}_{4 \mathrm{~b}}$ : Kepemilikan keluarga berpengaruh negatif pada agresivitas pajak (cash effective tax rate).

$\mathrm{H}_{4 \mathrm{c}}$ : Kepemilikan keluarga berpengaruh negatif pada agresivitas pajak (book tax difference).

\section{METODE PENELITIAN}

Penelitian dilakukan di Bursa Efek Indonesia (BEI) pada perusahaan yang termasuk ke dalam sektor manufaktur tahun 2013-2017. Perusahaan manufaktur 
dipilih karena merupakan sektor dengan kapitalisasi terbesar di Bursa Efek Indonesia serta memiliki aset tetap dengan jumlah besar. Penyusunan aset tetap berdasarkan pendekatan akuntansi akan menggambarkan dampak yang terjadi terhadap ketentuan perpajakan wajib pajak badan secara signifikan (Hartadinata dan Tjaraka, 2013). Objek penelitian adalah agresivitas pajak yang dijelaskan oleh kualitas audit, size, leverage, dan kepemilikan keluarga.

Pada penelitian ini agresivitas pajak diukur berdasarkan pengukuran yang digunakan dalam penelitian Rusydi dan Martani (2016) yaitu effective tax rate (ETR), cash effective tax rate (CETR), dan book tax difference (BTD). Beberapa peneliti menggunakan ETR sebagai proksi yang digunakan untuk mengukur agresivitas pajak diantaranya, Desai dan Dharmapala (2004), Graham dan Tucker (2006), Dyreng et al. (2008), Chen et al. (2010), serta Armstrong et al. (2012). ETR bertujuan untuk melihat beban pajak yang dibayarkan dalam tahun berjalan. Penelitian ini menggunakan rumus yang digunakan oleh Dyreng et al. (2008) untuk menghitung ETR yaitu sebagai berikut.

$$
\mathrm{ETR}=\frac{\text { Tax Expense } i, t}{\text { Pretax Income } i, t}
$$

Penelitian ini juga menggunakan pengukuran lain, yaitu cash effective tax rate (CETR). CETR telah digunakan oleh peneliti-peneliti terdahulu seperti Chen et al. (2010), Minnick dan Noga (2010), serta Hanlon dan Heitzman (2010). CETR bertujuan untuk mengakomodasikan jumlah kas pajak yang dibayarkan saat ini oleh perusahaan. Pada penelitian ini CETR dihitung dengan menggunakan pengukuran oleh Hanlon dan Heitzman (2010) yaitu sebagai berikut. 


$$
\text { CETR }=\frac{\text { Cash } \text { Tax Paid } \mathrm{i}, \mathrm{t}}{\text { Pretax } \text { Income } \mathrm{i}, \mathrm{t}}
$$

Selanjutnya, untuk memperkuat penelitian ini digunakan model book tax difference (BTD) yang dihitung dengan mengurangi laba akuntansi dengan laba fiskal yang merupakan perbedaan sementara (relatif) dan digambarkan dengan akun biaya (manfaat) pajak tangguhan. Model ini juga dapat mencerminkan strategi atau perilaku manajemen dalam mengelola pendapatan dan beban pajak (Tang dan Firth, 2011). Book tax difference (BTD) diperoleh dengan cara membagi pajak tangguhan dengan total aset menggunakan rumus Hanlon (2005) yaitu sebagai berikut.

$$
\mathrm{BTD}=\frac{\text { Total Dif Book-Tax i,t }}{\text { Total Asset } \mathrm{i}, \mathrm{t}}
$$

Maharani dan Suardana (2014) menjelaskan bahwa kualitas audit dapat diukur dengan menggunakan proksi ukuran Kantor Akuntan Publik. Ukuran Kantor Akuntan Publik digambarkan dengan dummy variable. Perusahaan yang menggunakan jasa Kantor Akuntan Publik The Big Four ditunjukkan dengan kode 1, sedangkan perusahaan yang menggunakan jasa Kantor Akuntan Publik non The Big Four ditunjukkan dengan kode 0. Kualitas Audit dilambangkan dengan KU (Vidiyanti, 2017).

Ukuran perusahaan adalah skala untuk mengukur besar kecilnya perusahaan melalui jumlah aset yang dimiliki perusahaan (Rodriguez dan Arias, 2012). Penelitian ini menggunakan proksi total aset perusahaan untuk mengetahui ukuran perusahaan yang dihitung dengan logaritma natural. Menurut Lanis dan Richardson (2012) rumus ukuran perusahaan tersebut adalah sebagai berikut. 
Ukuran Perusahaan $=$ Ln TA

Leverage merupakan rasio yang digunakan untuk mengukur kemampuan utang baik jangka panjang maupun jangka pendek untuk membiayai aset perusahaan. Leverage dapat didefinisikan sebagai besarnya persentase aset yang diperoleh melalui utang. Pada penelitian ini leverage dihitung dengan menggunakan rasio Debt to Total Aset (DTA). Leverage diukur dengan menggunakan rumus sebagai berikut.

$$
\text { DTA }=\frac{\text { Total Debt }}{\text { Total Asset }}
$$

Family ownership dalam Shyu (2011) didefinisikan sebagai kepemilikan individu di atas 5 persen dan kepemilikan dari perusahaan tertutup, bukan kepemilikan BUMN dan BUMD, perusahaan terbuka ataupun lembaga keuangan. Kepemilikan keluarga diukur dengan menggunakan rumus sebagai berikut.

$$
\text { FO }=\frac{\text { Total Saham Keluarga }}{\text { Total Saham Beredar }} \times 100 \% \text {. }
$$

Populasi penelitian adalah perusahaan sektor manufaktur yang terdaftar di Bursa Efek Indonesia (BEI) tahun 2013-2017. Sampel dalam penelitan ditentukan menggunakan metode nonprobability sampling dengan teknik purposive sampling, menggunakan beberapa kriteria diantaranya: (1) Perusahaan sektor manufaktur yang terdaftar di Bursa Efek Indonesia tahun 2013-2017; Perusahaan manufaktur yang mempublikasikan laporan tahunan (annual report) dan laporan keuangan tahunan secara lengkap; (3) Perusahaan manufaktur yang tidak mengalami kerugian selama tahun 2013-2017; (4) Perusahaan manufaktur 
dengan satuan mata uang rupiah; dan (5) Perusahaan manufaktur yang memiliki nilai ETR dan CETR antara 0-1.

Teknik analisis data yang digunakan adalah regresi linear berganda dengan melakukan uji asumsi klasik terlebih dahulu. Analisis regresi berganda dalam penelitian ini digunakan untuk menguji $\mathrm{H}_{1}, \mathrm{H}_{2}, \mathrm{H}_{3}$, dan $\mathrm{H}_{4}$ yaitu pengaruh kualitas audit, size, leverage, dan kepemilikan keluarga pada agresivitas pajak. Persamaan analisis regresi linear berganda adalah sebagai berikut.

$\mathrm{Y}=\alpha+\beta_{1} \mathrm{X}_{1}+\beta_{2} \mathrm{X}_{2}+\beta_{3} \mathrm{X}_{3}+\beta_{4} \mathrm{X}_{4}+\varepsilon$

Keterangan:

$\mathrm{Y} \quad$ : agresivitas pajak yang diproksikan dengan effective tax rate (ETR), cash effective tax rate (CETR), dan book tax difference (BTD)

$\alpha \quad$ : konstansta

$\beta \quad$ : koefisien regresi

$\mathrm{X}_{1} \quad$ : kualitas audit yang diukur dengan variabel dummy

$\mathrm{X}_{2}$ : ukuran perusahaan yang dihitung dengan $\ln$ (total aset)

$\mathrm{X}_{3} \quad$ : leverage yang dihitung dengan DTA

$\mathrm{X}_{4} \quad$ : kepemilikan keluarga yang diukur dengan membagi total saham keluarga dengan total saham beredar

$\varepsilon \quad$ : error term

\section{HASIL DAN PEMBAHASAN}

Uji statistik deskriptif digunakan untuk mendeskripsikan variabel-variabel dalam penelitian ini yaitu: (1) agresivitas pajak yang diproksikan dengan effective tax rate (ETR), cash effective tax rate (CETR), book tax difference (BTD); (2) kualitas audit (KU); (3) size (SIZE); (4) leverage (LEV); (5) dan kepemilikan keluarga (FO). Pengukuran yang digunakan dalam penelitian ini adalah nilai minimum, nilai maksimum, nilai rata-rata dan standar deviasi. Hasil uji statistik deskriptif dapat dilihat pada Tabel 2. 
Tabel 2.

Hasil Uji Statistik Deskriptif

\begin{tabular}{lccccc}
\hline & $\mathrm{N}$ & Minimum & Maximum & Mean & Std. Deviation \\
\hline ETR & 125 & 0,1680 & 0,3682 & 0,2520 & 0,0290 \\
CETR & 125 & 0,1269 & 0,9645 & 0,2985 & 0,1207 \\
BTD & 125 & 0,0000 & 0,0193 & 0,0031 & 0,0031 \\
KU & 125 & 0,0000 & 1,0000 & 0,6000 & 0,4918 \\
SIZE & 125 & 25,7957 & 33,3100 & 28,7591 & 1,6909 \\
LEV & 125 & 0,0662 & 0,7518 & 0,3419 & 0,1611 \\
FO & 125 & 0,0000 & 0,9818 & 0,6488 & 0,2670 \\
Valid N & 125 & & & & \\
(listwise) & & & & &
\end{tabular}

Berdasarkan Tabel 2. dapat diketahui nilai minimum, nilai maksimum, nilai rata-rata, dan standar deviasi dari masing-masing variabel penelitian. Variabel ETR yang berjumlah 125 pengamatan memiliki nilai minimum sebesar 0,1680 pada PT. Semen Baturaja Tbk (SMBR) tahun 2014 dan nilai maksimum sebesar 0,3682 pada PT. Pyridam Farma Tbk (PYFA) tahun 2014. Nilai rata-rata variabel ETR sebesar 0,2520 mempunyai arti bahwa nilai rata-rata beban pajak penghasilan dalam suatu perusahaan sebesar 25,20 persen dari laba sebelum pajaknya. Nilai standar deviasi variabel ETR sebesar 0,0290 menjelaskan bahwa terjadi perbedaan nilai variabel ETR yang diteliti terhadap nilai rata-ratanya sebesar 2,90 persen. Variabel CETR yang berjumlah 125 pengamatan memiliki nilai minimum sebesar 0,1269 pada PT. Ekadharma International Tbk (EKAD) tahun 2016 dan nilai maksimum sebesar 0,9645 pada PT. Industri Jamu dan Farmasi Sido Muncul (SIDO) tahun 2013. Nilai rata-rata variabel CETR sebesar 0,2985 mempunyai arti bahwa nilai rata-rata kas pajak dalam suatu perusahaan sebesar 29,85 persen dari laba sebelum pajaknya. Nilai standar deviasi variabel CETR sebesar 0,1207 menjelaskan bahwa terjadi perbedaan nilai variabel CETR yang diteliti terhadap nilai rata-ratanya sebesar 12,07 persen. Variabel BTD yang 
berjumlah 125 pengamatan memiliki nilai minimum sebesar 0,00 dan nilai maksimum sebesar 0,0193 pada PT. Multi Bintang Indonesia Tbk (MLBI) tahun 2013. Nilai rata-rata variabel BTD sebesar 0,0031 mempunyai arti bahwa nilai rata-rata pajak tangguhan dalam suatu perusahaan sebesar 0,3 persen dari total asetnya. Nilai standar deviasi variabel BTD sebesar 0,0031 menjelaskan bahwa terjadi perbedaan nilai variabel BTD yang diteliti terhadap nilai rata-ratanya sebesar 0,3 persen.

Variabel KU yang berjumlah 125 pengamatan memiliki nilai minimum sebesar 0,0000 dan nilai maksimum sebesar 1,0000. Nilai rata-rata variabel KU sebesar 0,6000 yang lebih besar dari 0,5 menunjukkan bahwa audit yang dilakukan oleh KAP The Big Four dengan kode 1 lebih banyak muncul dari 125 pengamatan. Dari 125 pengamatan, sebanyak 75 pengamatan menggunakan KAP The Big Four untuk mengaudit laporan keuangannya dan 50 pengamatan menggunakan jasa KAP non The Big Four untuk mengaudit laporan keuangannya. Nilai standar deviasi variabel KU sebesar 0,4918 menjelaskan bahwa terjadi perbedaan nilai variabel KU yang diteliti terhadap nilai rata-ratanya sebesar 49,18 persen.

Variabel SIZE yang berjumlah 125 pengamatan memiliki nilai minimum sebesar 25,7957 pada PT. Pyridam Farma Tbk (PYFA) tahun 2017 dan nilai maksimum sebesar 33,3100 pada PT. Astra International Tbk (ASII) tahun 2017. Nilai rata-rata variabel SIZE sebesar 28,7591 dan nilai standar deviasi variabel SIZE sebesar 1,6909 menjelaskan bahwa terjadi perbedaan nilai variabel SIZE yang diteliti terhadap nilai rata-ratanya sebesar 169 persen. 
Variabel LEV yang berjumlah 125 pengamatan memiliki nilai minimum sebesar 0,0662 pada PT.Industri Jamu dan Farmasi Sido Muncul Tbk (SIDO) tahun 2014 dan nilai maksimum sebesar 0,7518 pada PT. Multi Bintang Indonesia (MLBI) tahun 2014. Nilai rata-rata variabel LEV sebesar 0,3419 mempunyai arti bahwa dari total aset perusahaan sebesar 34,19 persen dibiayai dari hutang. Nilai standar deviasi variabel LEV sebesar 0,1611 menjelaskan bahwa terjadi perbedaan nilai variabel LEV yang diteliti terhadap nilai rata-ratanya sebesar 16,11 persen.

Variabel FO yang berjumlah 125 pengamatan memiliki nilai minimum sebesar 0,0000 pada PT. Indofood CBP Sukses Makmur Tbk (ICBP) dan PT. Semen Baturaja Tbk (SMBR) serta nilai maksimum sebesar 0,9818 pada PT. Hanjaya Mandala Sampoerna (HMSP) tahun 2013 dan tahun 2014. Nilai rata-rata variabel FO sebesar 0,6488 mempunyai arti bahwa dari keseluruhan total saham beredar sebesar 64,88 persen adalah saham dengan kepemilikan keluarga. Nilai standar deviasi variabel FO sebesar 0,2670 menjelaskan bahwa terjadi perbedaan nilai variabel FO yang diteliti terhadap nilai rata-ratanya sebesar 26,70 persen.

Berdasarkan hasil uji normalitas, nilai Asymp. Sig. (2-tailed) dari ketiga persamaan regresi lebih besar dari 0,05 yakni masing-masing sebesar 0,2 untuk model regresi 1 (effective tax rate), 0,078 untuk model regresi 2 (cash effective tax rate), dan 0,077 untuk model regresi 3 (book tax difference). Hal ini menunjukkan bahwa data penelitian berdistribusi normal. Hasil uji autokorelasi berada di antara $\mathrm{d}_{\mathrm{U}}$ dan $4-\mathrm{d}_{\mathrm{U}}(1,7745<1,846<2,2255),(1,7745<1,954<2,2255),(1,7745<$ $1,819<2,2255)$ atau berada pada daerah tidak terdapat autokorelasi, maka model 
regresi tidak mengandung gejala autokorelasi. Hasil uji multikolinearitas menunjukkan tidak ada nilai VIF yang lebih besar dari 10 sehingga model tersebut layak untuk memprediksi. Pada hasil uji heteroskedastisitas diketahui bahwa semua variabel bebas pada model regresi memiliki nilai signifikansi lebih besar dari 0,05 , maka model regresi penelitian ini bebas dari gejala heteroskedastisitas.

Uji regresi linear berganda dilakukan untuk mengetahui pengaruh kualitas audit $\left(\mathrm{X}_{1}\right)$, size $\left(\mathrm{X}_{2}\right)$, leverage $\left(\mathrm{X}_{3}\right)$, dan kepemilikan keluarga $\left(\mathrm{X}_{4}\right)$ pada agresivitas pajak (Y). Hasil uji regresi linear berganda dapat dilihat pada Tabel 3.

Tabel 3.

Hasil Uji Regresi Linear Berganda

\begin{tabular}{lllllll}
\hline \multirow{2}{*}{ Variabel } & \multicolumn{2}{c}{ ETR } & \multicolumn{2}{c}{ CETR } & \multicolumn{2}{c}{ BTD } \\
\cline { 2 - 7 } & koef & sig & Koef & Sig & koef & sig \\
\hline (Constant) & 0,427 & 0,000 & 0,033 & 0,875 & 0,0182 & 0,001 \\
KU & 0,002 & 0,826 & $-0,085$ & 0,000 & 0,0020 & 0,001 \\
SIZE & $-0,007$ & 0,249 & 0,009 & 0,203 & $-0,0006$ & 0,002 \\
LEV & 0,042 & 0,504 & $-0,016$ & 0,807 & 0,0012 & 0,495 \\
FO & 0,001 & 0,102 & 0,088 & 0,037 & $-0,0002$ & 0,879 \\
Adjusted R & 0,132 & & 0,095 & & 0,092 & \\
F $_{\text {hitung }}$ & 5,714 & & 4,251 & & 4,148 & \\
Sig. Fitung $_{\text {hiture }}$ & 0,000 & & 0,003 & & 0,003 & \\
\hline Sumber: Datan
\end{tabular}

Sumber: Data diolah, 2018

Berdasarkan Tabel 3 dapat disusun persamaan model regresi 1 (effective tax rate) sebagai berikut.

$$
\mathrm{Y}=0,427+0,002 \mathrm{X}_{1}-0,007 \mathrm{X}_{2}+0,042 \mathrm{X}_{3}+0,001 \mathrm{X}_{4}+\mathrm{e}
$$

Nilai konstanta $(\alpha)$ sebesar 0,427 memiliki arti bahwa apabila variabel KU, SIZE, LEV, dan FO dinyatakan konstan pada angka nol, maka nilai ETR akan meningkat sebesar 0,427 satuan.

Koefisien regresi variabel KU $\left(\beta_{1}\right)$ sebesar 0,002 menjelaskan bahwa peningkatan KU sebesar satu satuan akan meningkatkan ETR sebesar 0,002 satuan dengan asumsi variabel bebas lainnya konstan. 
Koefisien regresi variabel SIZE $\left(\beta_{2}\right)$ sebesar $-0,007$ menjelaskan bahwa peningkatan SIZE sebesar satu satuan akan menurunkan ETR sebesar 0,007 satuan dengan asumsi variabel bebas lainnya konstan.

Koefisien regresi variabel LEV $\left(\beta_{3}\right)$ sebesar 0,042 menjelaskan bahwa peningkatan LEV sebesar satu satuan akan meningkatkan ETR sebesar 0,042 satuan dengan asumsi variabel bebas lainnya konstan.

Koefisien regresi variabel FO $\left(\beta_{4}\right)$ sebesar 0,001 menjelaskan bahwa peningkatan FO sebesar satu satuan akan meningkatkan ETR sebesar 0,001 satuan dengan asumsi variabel bebas lainnya konstan.

Selanjutnya, berdasarkan Tabel 3 dapat disusun persamaan model regresi 2 (cash effective tax rate) sebagai berikut.

$$
Y=0,033-0,085 X_{1}+0,009 X_{2}-0,016 X_{3}+0,088 X_{4}+e
$$

Nilai konstanta $(\alpha)$ sebesar 0,033 memiliki arti bahwa apabila variabel KU, SIZE, LEV, dan FO dinyatakan konstan pada angka nol, maka nilai CETR akan meningkat sebesar 0,033 satuan.

Koefisien regresi variabel $\mathrm{KU}\left(\beta_{1}\right)$ sebesar $-0,085$ menjelaskan bahwa peningkatan KU sebesar satu satuan akan menurunkan CETR sebesar 0,085 satuan dengan asumsi variabel bebas lainnya konstan.

Koefisien regresi variabel SIZE $\left(\beta_{2}\right)$ sebesar 0,009 menjelaskan bahwa peningkatan SIZE sebesar satu satuan akan meningkatkan CETR sebesar 0,009 satuan dengan asumsi variabel bebas lainnya konstan. 
Koefisien regresi variabel LEV $\left(\beta_{3}\right)$ sebesar $-0,016$ menjelaskan bahwa peningkatan LEV sebesar satu satuan akan menurunkan CETR sebesar 0,016 satuan dengan asumsi variabel bebas lainnya konstan.

Koefisien regresi variabel FO $\left(\beta_{4}\right)$ sebesar 0,088 menjelaskan bahwa peningkatan FO sebesar satu satuan akan meningkatkan CETR sebesar 0,088 satuan dengan asumsi variabel bebas lainnya konstan.

Selanjutnya, berdasarkan Tabel 3 dapat disusun persamaan model regresi 3 (book tax difference) sebagai berikut.

$$
Y=0,0182+0,0020 X_{1}-0,0006 X_{2}+0,0012 X_{3}-0,0002 X_{4}+e
$$

Nilai konstanta $(\alpha)$ sebesar 0,0182 memiliki arti bahwa apabila variabel KU, SIZE, LEV, dan FO dinyatakan konstan pada angka nol, maka nilai BTD akan meningkat sebesar 0,0182 satuan.

Koefisien regresi variabel BTD $\left(\beta_{1}\right)$ sebesar 0,0020 menjelaskan bahwa peningkatan KU sebesar satu satuan akan meningkatkan BTD sebesar 0,0020 satuan dengan asumsi variabel bebas lainnya konstan.

Koefisien regresi variabel SIZE $\left(\beta_{2}\right)$ sebesar $-0,0006$ menjelaskan bahwa peningkatan SIZE sebesar satu satuan akan menurunkan BTD sebesar 0,0006 satuan dengan asumsi variabel bebas lainnya konstan.

Koefisien regresi variabel LEV $\left(\beta_{3}\right)$ sebesar 0,0012 menjelaskan bahwa peningkatan LEV sebesar satu satuan akan meningkatkan BTD sebesar 0,0012 satuan dengan asumsi variabel bebas lainnya konstan. 
Koefisien regresi variabel FO $\left(\beta_{4}\right)$ sebesar $-0,0002$ menjelaskan bahwa peningkatan FO sebesar satu satuan akan menurunkan BTD sebesar 0,0002 satuan dengan asumsi variabel bebas lainnya konstan.

Nilai adjusted $\mathrm{R}^{2}$ yang diperoleh model regresi 1 (effective tax rate), model regresi 2 (cash effective tax rate), dan model regresi 3 (book tax difference) masing-masing sebesar 0,$132 ; 0,095$; dan 0,092 . Hal ini berarti perubahan yang terjadi pada agresivitas pajak dapat dijelaskan oleh kualitas audit, size, leverage, dan kepemilikan keluarga masing-masing sebesar 13,2\%, 9,5\%, dan 9,2\%, sedangkan sisanya sebesar $86,8 \%, 90,5 \%$, dan $90,8 \%$ dijelaskan oleh faktor lain yang tidak diuji dalam penelitian.

Nilai $\mathrm{F}_{\text {hitung }}$ yang diperoleh model regresi 1 (effective tax rate), model regresi 2 (cash effective tax rate), dan model regresi 3 (book tax difference) masing-masing sebesar 5,714; 4,251; dan 4,418 dengan signifikansi 0,000; 0,003; dan 0,003 . Nilai signifikansi ini lebih kecil dari $0,05(\mathrm{~F}<\alpha)$ yang berarti bahwa model penelitian ini dinyatakan layak untuk digunakan sebagai model regresi.

Variabel kualitas audit $\left(\mathrm{X}_{1}\right)$ untuk model regresi 1 (effective tax rate) memiliki nilai signifikansi sebesar 0,725 lebih besar dari 0,05 menunjukkan bahwa kualitas audit tidak berpengaruh pada agresivitas pajak. Hal ini berarti hipotesis pertama $\left(\mathrm{H}_{1 \mathrm{a}}, \mathrm{H}_{1 \mathrm{~b}}, \mathrm{H}_{1 \mathrm{c}}\right)$ ditolak. Hal ini disebabkan karena audit yang dilakukan oleh setiap Kantor Akuntan Publik berpedoman pada standar pengendalian mutu kualitas audit yang telah ditetapkan oleh Dewan Standar Profesional Akuntan Publik Institut Akuntan Publik Indonesia (DSPAP IAPI) serta aturan etika akuntan publik yang ditetapkan oleh IAPI (Winata, 2014). 
Peraturan tersebut wajib dilakukan oleh seluruh auditor baik yang bergabung dengan Kantor Akuntan Publik The Big Four maupun non The Big Four, sehingga tindakan agresivitas pajak dapat dilakukan oleh manajemen perusahaan baik dengan auditor yang tergabung ke dalam Kantor Akuntan Publik The Big Four maupun non The Big Four (Kusuma dan Firmansyah, 2018).

Variabel kualitas audit $\left(\mathrm{X}_{1}\right)$ untuk model regresi 2 (cash effective tax rate) memiliki nilai signifikansi uji t sebesar 0,000 yang kurang dari 0,05 menunjukkan bahwa kualitas audit berpengaruh negatif pada agresivitas pajak. Hal ini berarti hipotesis pertama $\left(\mathrm{H}_{1 \mathrm{~b}}\right)$ diterima. Agresivitas pajak dapat dikategorikan sebagai suatu masalah keagenan akibat adanya asimetri informasi antara pemilik dengan manajer perusahaan. Salah satu cara yang dapat dilakukan oleh pemilik perusahaan untuk meminimalisir adanya asimetri informasi adalah dengan menggunakan auditor berkualitas dalam mengaudit laporan keuangannya (Purwanti dan Rahardjo, 2012). Perusahaan yang diaudit oleh Kantor Akuntan Publik The Big Four akan semakin sulit melakukan kebijakan pajak agresif (Dewi dan Jati, 2014).

Variabel kualitas audit $\left(\mathrm{X}_{1}\right)$ untuk model regresi 3 (book tax difference) memiliki nilai signifikansi uji t sebesar 0,001 yang kurang dari 0,05 menunjukkan bahwa kualitas audit berpengaruh positif pada agresivitas pajak. Hal ini berarti hipotesis pertama $\left(\mathrm{H}_{1 \mathrm{a}}, \mathrm{H}_{1 \mathrm{~b}}, \mathrm{H}_{1 \mathrm{c}}\right)$ ditolak. Hasil penelitian ini sejalan dengan Dewi dan Sari (2015), Marfiah dan Syam (2016), serta Eksandy (2017). Semakin baik kualitas audit, maka tindakan agresivitas pajak yang dilakukan perusahaan akan meningkat. Penjelasan dari penyataan tersebut adalah meskipun perusahaan 
menggunakan jasa Kantor Akuntan Publik The Big Four dalam mengaudit laporan keuangannya, hal tersebut tidak menghalangi perusahaan dalam melakukan tindakan penghindaran pajak karena fungsi auditor hanya menguji kewajaran informasi laporan keuangan suatu perusahaan (Dewi dan Sari, 2015).

Variabel size $\left(\mathrm{X}_{2}\right)$ untuk model regresi 1 (effective tax rate) memiliki nilai signifikansi uji t sebesar 0,000, sedangkan untuk model regresi 3 (book tax difference) diketahui nilai signifikansi uji t untuk variabel size $\left(\mathrm{X}_{2}\right)$ sebesar 0,002 . Signifikansi sebesar 0,000 dan 0,002 yang kurang dari 0,05 menunjukkan bahwa size berpengaruh negatif pada agresivitas pajak yang berarti hipotesis kedua $\left(\mathrm{H}_{2 \mathrm{a}}\right.$, $\mathrm{H}_{2 \mathrm{~b}}, \mathrm{H}_{2 \mathrm{c}}$ ) ditolak. Sejalan dengan hasil penelitian Nugraha dan Meiranto (2015), Dewi dan Noviari (2017), serta Gemilang (2017) yaitu size berpengaruh negatif pada agresivitas pajak. Hal ini disebabkan karena perusahaan besar cenderung melaporkan lebih akurat mengenai keadaan perusahaannya, sehingga manajer dalam perusahaan besar memiliki celah yang lebih kecil untuk melakukan manipulasi khususnya beban pajak terhutangnya dibandingkan dengan manajer di perusahaan kecil (Dewi dan Noviari, 2017). Teori biaya politik menjelaskan bahwa tindakan agresivitas pajak dalam perusahaan besar cenderung lebih rendah karena perusahaan besar akan menjadi perhatian pemerintah (Gemilang, 2017).

Variabel size $\left(\mathrm{X}_{2}\right)$ untuk model regresi 2 (cash effective tax rate) memiliki nilai signifikansi uji t sebesar 0,203 yang lebih besar dari 0,05 menunjukkan bahwa size tidak berpengaruh pada agresivitas pajak. Hal ini berarti hipotesis kedua $\left(\mathrm{H}_{2 \mathrm{a}}, \mathrm{H}_{2 \mathrm{~b}}, \mathrm{H}_{2 \mathrm{c}}\right)$ ditolak. Tidak berpengaruhnya ukuran perusahaan pada tindakan agresivitas pajak dapat dilihat dari dua sisi. Di satu sisi baik perusahaan 
besar maupun perusahaan kecil wajib membayar pajak kepada negara. Perusahaan besar dan kecil tetap diperiksa oleh fiskus apabila tidak mematuhi peraturan perpajakan (Putri, 2016). Di sisi lain, tidak berpengaruhnya ukuran perusahaan pada tindakan agresivitas pajak disebabkan karena lemahnya pengawasan fiskus terhadap pelaku bisnis dan menyebabkan tindakan penghindaran pajak menyebar pada seluruh ukuran perusahaan (Rusydi, 2013).

Variabel leverage $\left(\mathrm{X}_{3}\right)$ untuk model regresi 1 (effective tax rate) memiliki nilai signifikansi uji t sebesar 0,009 yang kurang dari dari 0,05 menunjukkan bahwa leverage berpengaruh positif pada agresivitas pajak. Hal ini berarti hipotesis ketiga $\left(\mathrm{H}_{3 \mathrm{a}}, \mathrm{H}_{3 \mathrm{~b}}, \mathrm{H}_{3 \mathrm{c}}\right)$ ditolak. Hasil ini sejalan dengan penelitian Sukmawati dan Rebecca (2016) serta Fadli dkk. (2016). Berdasarkan teori trade off, pendanaan keuangan perusahaan yang berasal dari penggunaan hutang dapat memberi manfaat sebagai pengurang beban pajak. Kebijakan keputusan pendanaan yang ditetapkan oleh perusahaan dapat digambarkan melalui rasio leverage yang dimiliki perusahaan (Arianandini dan Ramantha, 2018). Pasal 6 ayat (1) huruf a UU Nomor 36 Tahun 2008 menyebutkan bahwa bunga sebagai bagian dari biaya usaha dapat dikurangkan sebagai biaya (tax deductible) dalam proses penghitungan Pajak Penghasilan $(\mathrm{PPh})$ badan.

Variabel leverage $\left(\mathrm{X}_{3}\right)$ untuk model regresi 2 (cash effective tax rate) memiliki nilai signifikansi uji t sebesar 0,807, sedangkan untuk model regresi 3 (book tax difference) diketahui nilai signifikansi uji t untuk variabel leverage $\left(\mathrm{X}_{3}\right)$ sebesar 0,495. Signifikansi sebesar 0,807 dan 0,495 yang lebih besar dari 0,05 menunjukkan bahwa leverage tidak berpengaruh pada agresivitas pajak. Hal ini 
berarti hipotesis ketiga $\left(\mathrm{H}_{3 \mathrm{a}}, \mathrm{H}_{3 \mathrm{~b}}, \mathrm{H}_{3 \mathrm{c}}\right)$ ditolak. Hasil penelitian ini sejalan dengan Darmawan dan Sukartha (2014), Tiaras dan Wijaya (2015), serta Vidiyanti (2017). Semakin tinggi tingkat hutang suatu perusahaan, maka pihak manajemen akan lebih konservatif dalam melakukan pelaporan keuangan atau operasional perusahaan. Perusahaan menghindari pembiayan yang berasal dari 100 persen hutang dengan memperhitungkan biaya hutang atau financial distress yang mengakibatkan perusahaan tidak dapat mencapai keuntungan optimal apabila pembiayaan berasal dari 100 persen hutang (Arianandini dan Ramantha, 2018).

Variabel kepemilikan keluarga $\left(\mathrm{X}_{4}\right)$ untuk model regresi 1 (effective tax rate) memiliki nilai signifikansi uji $\mathrm{t}$ sebesar 0,895 , sedangkan untuk model regresi 3 (book tax difference) diketahui nilai signifikansi uji t untuk variabel kepemilikan keluarga $\left(\mathrm{X}_{4}\right)$ sebesar 0,879. Signifikansi sebesar 0,895 dan 0,879 yang lebih besar dari 0,05 menunjukkan bahwa kepemilikan keluarga tidak berpengaruh pada agresivitas pajak. Hal ini berarti hipotesis keempat $\left(\mathrm{H}_{4 \mathrm{a}}, \mathrm{H}_{4 \mathrm{~b}}\right.$, $\mathrm{H}_{4 \mathrm{c}}$ ) ditolak. Hasil penelitian ini sejalan dengan Fatharani (2012) serta Utami dan Setyawan (2015). Di Indonesia, reputasi keluarga bukan menjadi prioritas utama, namun lebih mengutamakan laba yang maksimal sehingga perusahaan melakukan penghindaran pajak atau tidak menjadi hal yang diabaikan. Kemungkinan lain adalah saham yang tercatat di perusahaan adalah saham keluarga, namun kenyataannya bukanlah saham keluarga melainkan saham yang dimiliki oleh beberapa orang atas nama keluarga (Aditama, 2016). Selain itu, kepemilikan keluarga dalam penelitian ini mengambil model piramida yakni kepemilikan secara tidak langsung, sehingga kepemilikan keluarga tidak ditunjukkan secara 
eksplisit dalam laporan keuangan tahunan. Hal ini menyebabkan peneliti memberikan adjustment bahwa kepemilikan Perseroan Terbatas yang dijelaskan dalam akun modal saham pada laporan keuangan tahunan dianggap sebagai kepemilikan keluarga, sehingga fungsinya dalam penghindaran pajak tidak signifikan (Rusydi dan Martani, 2016).

Variabel kepemilikan keluarga $\left(\mathrm{X}_{4}\right)$ untuk model regresi 2 (cash effective tax rate) memiliki nilai signifikansi uji t sebesar 0,037. Signifikansi sebesar 0,037 yang kurang dari 0,05 menunjukkan bahwa kepemilikan keluarga berpengaruh positif pada agresivitas pajak. Hal ini berarti hipotesis keempat $\left(\mathrm{H}_{4 \mathrm{a}}, \mathrm{H}_{4 \mathrm{~b}}, \mathrm{H}_{4 \mathrm{c}}\right)$ yang menyatakan bahwa kepemilikian keluarga berpengaruh negatif pada agresivitas pajak ditolak. Bagi perusahaan keluarga agresivitas pajak bukan hanya digunakan untuk tujuan penghematan pajak, tetapi juga mengurangi rent extraction. Rent extraction dapat dianggap sebagai agency cost bagi perusahaan (Steijvers dan Niskanen, 2014). Teori akuntansi positif menjelaskan bagaimana manajemen perusahaan menggunakan metode akuntansi yang paling sesuai untuk mengambil tindakan dalam pelaporan keuangan. Manajemen dapat dipengaruhi oleh pemegang saham mayoritas yang merupakan anggota keluarga untuk bertindak sesuai dengan keinginan pemilik perusahaan, salah satunya melakukan tindakan agresivitas pajak. Keluarga yang merupakan pemilik mayoritas perusahaan memiliki hak suara yang lebih besar dibandingkan pemilik saham lainnya. Kondisi ini menyebabkan keluarga sebagai pemilik perusahaan dapat menentukan arah kebijakan yang diambil kedepannya (Wirawan dan Sukartha, 2018). 


\section{SIMPULAN}

Berdasarkan hasil penelitian dapat disimpulkan bahwa Kualitas audit berpengaruh negatif pada agresivitas pajak yang diukur dengan cash effective tax rate (CETR). Hasil ini sejalan dengan teori agensi yang dapat mengurangi asimetri informasi dalam perusahaan dengan menggunakan auditor yang berkualitas dalam mengaudit laporan keuangannya. Sebaliknya pengukuran dengan menggunakan book tax difference (BTD) memperoleh hasil bahwa kualitas audit berpengaruh positif pada agresivitas pajak karena tidak menutup kemungkinan bagi akuntan publik yang bereputasi baik untuk tidak melakukan agresivitas pajak. Size berpengaruh negatif pada agresivitas pajak yang diukur dengan effective tax rate (ETR) dan book tax difference (BTD). Hasil ini sejalan dengan teori biaya politik, bahwa semakin besar ukuran suatu perusahaan, maka semakin rendah tindakan agresivitas pajak yang dilakukan perusahaan tersebut karena perusahaan besar cenderung menjadi sorotan pemerintah ataupun fiskus. Leverage berpengaruh positif pada agresivitas pajak yang diukur dengan effective tax rate (ETR). Hasil ini sejalan dengan teori trade off, bahwa besarnya nilai leverage akan meningkatkan tindakan agresivitas pajak dalam perusahaan apabila beban bunga yang timbul akibat penggunaan hutang termasuk ke dalam beban yang dapat mengurangi penghasilan kena pajak (deductible expense). Pengukuran yang dilakukan dengan cash effective tax rate (CETR) memperoleh hasil bahwa kepemilikan keluarga berpengaruh positif pada agresivitas pajak. Sejalan dengan teori akuntansi positif yang menjelaskan bagaimana manajemen perusahaan 
menggunakan metode akuntansi yang paling sesuai untuk mengambil tindakan dalam pelaporan keuangan.

Saran yang diberikan peneliti untuk peneliti selanjutnya adalah peneliti selanjutnya disarankan untuk dapat melakukan penelitian kembali di perusahaan sektor lainnya yang terdaftar di BEI dengan periode pengamatan yang berbeda. Selain itu, hasil uji koefisien determinasi (adjusted $\mathrm{R}^{2}$ ) dalam penelitian ini yaitu sebesar 13,2\% untuk proksi effective tax rate, 9,5\% untuk proksi cash effective tax rate, dan 9,2\% untuk proksi book tax difference. Rendahnya hasil koefisien menunjukkan bahwa kemampuan variabel independen dalam menjelaskan variasi dependennya cukup terbatas, sehingga peneliti selanjutnya dapat menambah variabel independen lain yang dapat berpengaruh terhadap agresivitas pajak seperti corporate social responsibility, capital intensity, corporate governance, dan manajemen laba. Kemudian, diharapkan perusahaan dapat meningkatkan pengawasan kepada pihak manajemen agar tidak melanggar ketentuan-ketentuan akuntansi dan perpajakan dengan memaksimalkan penggunaan e-faktur serta menerapkan corporate governance dengan baik.

\section{REFERENSI}

Adisamartha, I. B. P. F., \& Noviari, N. (2015). Pengaruh Likuiditas, Leverage, Intensitas Persediaan, dan Intensitas Aset Tetap pada Tingkat Agresivitas Wajib Pajak Badan. E-Jurnal Akuntansi Universitas Udayana, 13(3), 9731000 .

Aditama, A. (2016). Pengaruh Profitabilitas, Kepemilikan Keluarga, Corporate Governance, Leverage, Ukuran Perusahaan, Kualitas Audit, dan Kepemilikan Institusional terhadap Penghindaran Pajak. Skripsi Universitas Muhammadiah Yogyakarta. 
Arianandini, P. W., \& Ramantha, I. W. (2018). Pengaruh Profitabilitas, Leverage, dan Kepemilikan Institusional pada Tax Avoidance. E-Jurnal Akuntansi Universitas Udayana, 22(3), 2088-2116.

Armstrong, C. S., Blouin, J. L., \& Larcker, D. F. (2012). The Incentives for Tax Planning. Journal of Accounting and Economics, 53(1-2), 391-411.

Chen, S., Chen, X., \& Cheng, Q. (2010). Are Family Firms More Tax Aggressive Than Non-family Firms? Journal of Financial Economics, 95(1), 41-61.

Chu, W. (2009). Family Ownership and Firm Performance: Influence of Family Management, Family Control, and Firm Size. Asia Pacific Journal of Management, 28(4), 833-851.

Darmawan, H., \& Sukartha, M. (2014). Pengaruh Penerapan Corporate Governance, Leverage, Return On Assets, dan Ukuran Perusahaan pada Penghindaran Pajak. E-Jurnal Akuntansi Universitas Udayana, 9(1), 143161.

Deangelo, L. E. (1981). Auditor Size and Audit Quality. Journal of Accounting and Economics, 3(3), 183-199.

Desai, M. A., \& Dharmapala, D. (2004). Corporate Tax Avoidance and High Powered Incentives. Departement of Economics Working Paper Series.

Dewi, G. A. P., \& Sari, M. M. R. (2015). Pengaruh Insentif Eksekutif, Corporate Risk, dan Corporate Governance pada Tax Avoidance. E-Jurnal Akuntansi Universitas Udayana, 13(1), 50-67.

Dewi, N. L. P. P., \& Noviari, N. (2017). Pengaruh Ukuran Perusahaan, Leverage, Profitabilitas, dan Corporate Social Responsibility terhadap Penghindaran Pajak (Tax Avoidance). E-Jurnal Akuntansi Universitas Udayana, 21(1), 830-859.

Dewi, N. N., \& Jati, I. K. (2014). Pengaruh Karakter Eksekutif, Karakteristik Perusahaan, dan Dimensi Tata Kelola Perusahaan yang Baik pada Tax Avoidance di Bursa Efek Indonesia. E-Jurnal Akuntansi Universitas Udayana, 6(2), 249-260.

Dharma, S., \& Ardiana, A. (2016). Pengaruh Leverage, Intensitas Aset Tetap, Ukuran Perusahaan, dan Koneksi Politik terhadap Tax Avoidance. E-Jurnal Akuntansi Universitas Udayana, 15(1), 584-613.

Dyreng, S. D., Hanlon, M., \& Maydew, E. L. (2008). Long-Run Corporate Tax Avoidance. The Accounting Revieweview, 83(1), 61-82. 
Eksandy, A. (2017). Pengaruh Komisaris Independen, Komite Audit, dan Kualitas Audit terhadap Penghindaran Pajak (Tax Avoidance). Jurnal Competitive, 1(1).

Fadli, I., Ratnawati, V., \& Kurnia, P. (2016). Pengaruh Likuiditas, Leverage, Komisaris Independen, Manajemen Laba, dan Kepemilikan Institusional terhadap Agresivitas Pajak Perusahaan. Jurnal Jom Fekon, 3(1), 1205-1219.

Fatharani, N. (2012). Pengaruh Karakterisitik Kepemilikan, Reformasi Perpajakan, dan Hubungan Politik terhadap Tindakan Pajak Agresif pada Perusahaan yang Terdaftar di Bursa Efek Indonesia pada Tahun 2007-2010. Skripsi Universitas Indonesia.

Frank, M. M., Lynch, L. J., \& Rego, S. O. (2009). Tax Reporting Aggressiveness and Its Relation to Aggressive Financial Reporting. The Accounting Review, 84(2), 467-496.

Gemilang, D. N. (2017). Pengaruh Likuiditas, Leverage, Profitabilitas, Ukuran Perusahaan, dan Capital Intensity terhadap Agresivitas Pajak Perusahaan (Studi Empiris pada Perusahaan Property dan Real Estate yang Terdaftar di BEI pada Tahun 2013-2015). Skripsi Institut Agama Islam Negeri Surakarta.

Graham, J. R., \& Tucker, A. L. (2006). Tax Shelters and Corporate Debt Policy. Journal of Financial Economics, 81(3), 563-594.

Hanlon, M. (2005). The Persistence and Pricing of Earnings, Accruals, and Cash Flows When Firms Have Large Book- Tax Differences. The Accounting Review, 80(1), 137-166.

Hanlon, M., \& Heitzman, S. (2010). A Review of Tax Research. Journal of Accounting and Economics, 50(2-3), 127-178.

Hartadinata, O. S., \& Tjaraka, H. (2013). Analisis Pengaruh Kepemilikan Manajerial, Kebijakan Hutang, dan Ukuran Perusahaan terhadap Tax Aggressiveness pada Perusahaan Manufaktur di Bursa Efek Indonesia 20082010. Jurnal Ekonomi dan Bisnis Tahun XXXIII, (3), 48-59.

Jensen, M. C., \& Meckling, W. H. (1976). Theory of the Firm: Managerial Behavior, Agency Costs and Ownership Structure. Journal of Financial Economics, 3, 305-360.

Kanagaretnam, K., Lee, J., Lim, C. Y., \& Lobo, G. J. (2016). Relation Between Auditor Quality and Tax Aggressiveness: Implications of Cross-Country Institutional Differences. Auditing: A Journal of Practice and Theory, 35(4), 
Kasmir. (2014). Analisis Laporan Keuangan (Pertama). Jakarta: PT. Rajagrafindo Persada.

Khairunisa, K., Hapsari, D. W., \& Aminah, W. (2017). Pengaruh Kualitas Audit, Corporate Social Responsibility, dan Ukuran Perusahaan terhadap Tax Avoidance. Jurnal Riset Akuntansi Kontemporer (JRAK), 9(1), 36-43.

Kurniasih, T., \& Sari, M. M. R. (2013). Pengaruh Return on Assets, Leverage, Corporate Governance, Ukuran Perusahaan, dan Kompensasi Rugi Fiskal pada Tax Avoidance. Buletin Studi Ekonomi, 18(1), 58-66.

Kusuma, C. A., \& Firmansyah, A. (2018). Manajemen Laba, Corporate Governance, Kualitas Auditor Eksternal, dan Agresivitas Pajak. Jurnal Tekun, 8(1), 108-123.

Lanis, R., \& Richardson, G. (2012). Corporate Social Responsibility and Tax Aggressiveness: a Test of Legitimacy Theory. Accounting, Auditing \& Accountability Journal, 26(1), 75-100.

Maharani, I. G. A. C., \& Suardana, K. A. (2014). Pengaruh Corporate Governance, Profitabilitas, dan Karakteristik Eksekutif pada Tax Avoidance Perusahaan Manufaktur. E-Jurnal Akuntansi Universitas Udayana, 9(2), $525-539$.

Marfiah, D., \& Syam, F. (2016). Pengaruh Corporate Governance dan Leverage terhadap Tax Avoidance pada Perusahaan Manufaktur yang Terdaftar di Bursa Efek Indonesia (BEI) Tahun 2011-2015. Jurnal Ilmiah Mahasiswa Ekonomi Akuntansi, 1(2), 91-102.

Minnick, K., \& Noga, T. (2010). Do Corporate Governance Characteristics Influence Tax Management? Journal of Corporate Finance, 16, 703-718.

Mustika, Ratnawati, V., \& Silfi, A. (2017). Pengaruh Corporate Social Responsibility, Ukuran Perusahaan, Profitabilitas, Leverage, Capital Intensity, dan Kepemilikan Keluarga terhadap Agresivitas Pajak. Jurnal Jom Fekon, 4(1), 1886-1900.

Nugraha, N. B., \& Meiranto. (2015). Pengaruh Corporate Social Responsibility, Ukuran Perusahaan, Profitabilitas, Leverage, dan Capital Intensity terhadap Agresivitas Pajak. Diponegoro Journal of Accounting, 4(4), 1-14.

Purwanti, R. B., \& Rahardjo, S. N. (2012). Pengaruh Kecakapan Manajerial, Kualitas Auditor, Komite Audit, Firm Size, dan Leverage terhadap Earnings Management. Diponegoro Journal of Accounting, 1(1), 1-12. 
Putri, A. M. (2016). Pengaruh Kepemilikan Keluarga, Leverage, dan Ukuran Perusahaan terhadap Tax Aggressiveness pada Perusahaan Manufaktur yang Terdaftar di BEI Periode 2012-2015. Skripsi Universitas Airlangga.

Richardson, G., \& Lanis, R. (2007). Determinants of The Variability in Corporate Effective Tax Rates and Tax Reform: Evidence From Australia. Journal of Accounting and Public Policy, 26, 689-704.

Rodriguez, E. F., \& Arias, A. M. (2012). Do Business Characteristics Determine an Effective Tax Rate? Chinese Economy, 45(6), 60-83.

Rusydi, M. K. (2013). Pengaruh Ukuran Perusahaan terhadap Aggressive Tax Avoidance di Indonesia. Jurnal Akuntansi Multiparadigma, 4(2), 322-329.

Rusydi, M. K., \& Martani, D. (2016). Pengaruh Struktur Kepemilikan terhadap Aggressive Tax Avoidance. Simposium Nasional Akuntansi, XVII.

Sari, D. K., \& Martani, D. (2010). Ownership Characteristics, Corporate Governance, and Tax Aggressiveness. Accounting Conference, 27-28.

Shyu, J. (2011). Family Ownership and Firm Performance: Evidence from Taiwanese Firms. International Journal of Managerial Finance, 7(4), 397411.

Steijvers, T., \& Niskanen, M. (2014). Tax Aggressiveness in Private Family Firms: an Agency Perspective. Journal of Family Business Strategy, 5(4), 347-357.

Sukmawati, F., \& Rebecca, C. (2016). Pengaruh Likuiditas dan Leverage terhadap Agresivitas Pajak Perusahaan pada Perusahaan Industri Barang Konsumsi di Bursa Efek Indonesia Periode 2011-2014. Conference on Management and Behavioral Studies, 498-509.

Tang, T., \& Firth, M. (2011). Can Book-Tax Differences Capture Earnings Management and Tax Management? Empirical Evidence from China. The International Journal of Accounting, Forthcoming.

Tiaras, I., \& Wijaya, H. (2015). Pengaruh Likuiditas, Leverage, Manajemen Laba, Komisaris Independen, dan Ukuran Perusahaan terhadap Agresivitas Pajak. Jurnal Akuntansi Universitas Tarumanagara Jajarta, XIX(03), 380-397.

Utami, W. T., \& Setyawan, H. (2015). Pengaruh Kepemilikan Keluarga terhadap Tindakan Pajak Agresif dengan Corporate Governance Sebagai Variabel Moderating (Studi Empiris pada Perusahaan Manufaktur yang Terdaftar di Bursa Efek Indonesia Tahun 2010-2013. Journal Conference in Business, Accounting, and Management, 2(1), 413-421. 
Vidiyanti, E. (2017). Pengaruh Komite Audit, Kualitas Audit, Kepemilikan Institusional, Return On Assets, dan Leverage terhadap Tax Avoidance. Skripsi STIE Perbanas Surabaya.

Watts, R. L., \& Zimmerman, J. L. (1990). Positive Accounting Theory: A Ten Year Perspective. The Accounting Review, 65(1), 131-156.

Wijayani, R. D. (2016). Pengaruh Profitabilitas, Kepemilikan Keluarga, Corporate Governance, dan Kepemilikan Institusional terhadap Penghindaran Pajak di Indonesia (Studi Empiris Perusahaan Manufaktur yang Terdaftar di BEI tahun 2012-2014). Jurnal Dinamika Ekonomi \& Bisnis, 13(2), 181-192.

Winata, F. (2014). Pengaruh Corporate Governance terhadap Tax Avoidance pada Perusahaan yang Terdaftar di Bursa Efek Indonesia Tahun 2013. Tax \& Accounting Review, 4(1), 1-11.

Wirawan, I. G. H. K., \& Sukartha, I. M. (2018). Pengaruh Kepemilikan Keluarga dan Ukuran Perusahaan pada Agresivitas Pajak dengan Corporate Governance Sebagai Variabel Pemoderasi. E-Jurnal Akuntansi Universitas Udayana, 23(1), 595-625. 